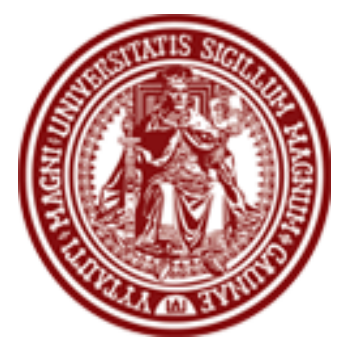

DE DE GRUYTER OPEN

\section{BALTIC JOURNAL OF LAW \& POLITICS}

A Journal of Vytautas Magnus University

VOLUME 7, NUMBER 2 (2014)

ISSN 2029-0454

\title{
THE RISE OF ANTI-ROMA POSITIONS IN SLOVAKIA AND HUNGARY: A NEW SOCIAL AND POLITICAL DIMENSION OF NATIONALISM
}

\author{
Jaroslav Mihálik \\ Assistant Professor; Researcher; Ph.D. \\ University of Ss. Cyril and Methodius in Trnava, Faculty of Social Sciences \\ (Slovakia) \\ Contact information \\ Address: 4/A Bucianska St., 91701 Trnava, Slovakia \\ Phone: +421904 453443 \\ E-mail address: jaroslav.mihalik@ucm.sk
}

Received: March 25, 2014; reviews: 2; accepted: December 29, 2014.

\begin{abstract}
This article discusses the continuous substitution of traditional mutual conflicts and historical grievances between Slovakia and Hungary that has created fertile ground for nationalists on both sides. Currently, we witness the rise of anti-Roma positions and negativism oriented toward this particular group of the population in Slovakia and Hungary. For this reason, we track the sources of new nationalism associated with the hatred of the Roma population. This can be demonstrated by a variety of political incentives and measuring extremism as a tool of acquiring and maintaining political power. The aim of the article is to investigate the extent and reasons of the new social and political dimensions of Slovak and Hungarian nationalism. We assume that the traditional form of bilateral nationalism based on historical, political and social tensions between Slovakia and Hungary is
\end{abstract}


being transformed by the ethnic nationalism against the Roma minority in Central Europe. To support our argumentation, we use the qualitative data from in-depth interviews with young respondents from two contrasting research field sites in Slovakia from EC research project MYPLACE (Memory, Youth, Political Legacy and Civic Engagement).

\section{KEYWORDS}

Nationalism, Slovakia, Hungary, anti-Roma, extremism, radicalism 


\section{INTRODUCTION}

In dealing with minority relations analysis the scope of the research is vested in developments in the region of Central Europe. Throughout the twentieth century the region was a testing ground for a variety of socio-political regimes that can hardly be characterized as democratic. With the exception of the creation of new nation-states as an output of the dissolution of the Austrian-Hungarian monarchy after the end of the World War I, the periods during the following decades are considered negative and even tragic with regard to the status of the civil societymutatis mutandis for minority group members.

Only the last decade of the previous century enabled the countries of Central Europe to return to a Western type of democracy. The final collapse of the Soviet Union and the subsequent revival of society and the political establishment showed a wave of further development. One of the many critical developments in the postSoviet era was the renewal and boost of the European integration process. Together with policy-making, there was also the need to protect the fundamental rights and freedoms of national minorities living in the territories of the respective sovereign states. The national policy making toward the minorities was essential in the democracy-building procedures in the countries of CEE. ${ }^{1}$ The consolidation of democracy was often, as scholars have observed, related to the treatment of national minorities. ${ }^{2}$

Apparently, the spectrum of the countries in this region adopted different approach and methods in promoting the citizenship or status for minority members. These differences are basically seen in the various regions of post-Soviet Europe. While in the Visegrad group countries the major disputes are still very related to the consequences of the Austro-Hungarian monarchy, the Baltic States region can be classified as a historical grievance and rejection of Russification and Sovietization of the Baltic societies. In the case of former Yugoslavia there were civic and secular dimensions of the ethnic conflicts in the common federation.

From the perspective and focus on the region of Central Europe, we should admit another well-known minority conflict-the situation, position, and integration of Roma minority. This observance, together with the management of SlovakHungarian nationalism, will be central to this article. The major discourse in mutual Slovak-Hungarian relations is closely associated with ethnic nationalism, language issues, and historical grievances. Specifically, these relations escalated into various

\footnotetext{
1 Rogers Brubaker, Nationalism Reframed: Nationhood and the National Question in the New Europe (Cambridge: Cambridge University Press, 1996), p. 83-84.

2 Břetislav Dančák and Petr Fiala, Národnostní politika v postkomunistických zemích (Brno: Masarykova univerzita, 2000).
} 
political battles of rhetoric, setting up the nationalist political agenda of political parties and the emergence of radicalism on both sides. ${ }^{3}$

Apart from the national governments, an important role in minority integration is played by supranational organizations, such as the Council of Europe, the Organization for Security and Cooperation in Europe, together with the EU institutions, most notably the European Commission. When looking back to the last two waves of European integration, 2004 and 2007, these showed the permanent need of monitoring the consequences of historical development in the European regions. The trauma caused by two World Wars, the Cold War crisis, and the conflict in the Balkans, confirmed the urgent need to keep an eye on the global security environment. Here we stress the revitalized dilemmas of nationalism, ethnic conflicts, and different approaches to minority policy-making in the postSoviet area. The countries represented in this bloc belong to a group of heterogeneous countries, even though it is practically impossible to talk about any one European country as a homogeneous one, considering the ethnic structure of the state.

There has been widespread research on the largest minority group in Europe - the Roma. The majority of this research deal with the social integration phenomena. An example of such analysis in twelve countries of Europe might be the thematic issue of Social Sciences Eastern Europe published by GESIS, ${ }^{4}$ publication "Roma: A European Minority ..." ${ }^{5}$ or the very recent survey report published in 2012 by the European Union Agency for Fundamental Rights. ${ }^{6}$ Another vital source of complex studies of the Roma population in Europe is the influential contribution of Aidan McGarry, who follows the nexus and structure of cross national political participation and representation of Roma. ${ }^{7}$

Due to the complexity of the research problem, this article consists of multiple sections. First, the article focuses on the traditional conflict line that had created the bias for rise of nationalism between Slovaks and Hungarians since the 90's. We identify the developments and obstacles in minority policy-making in the selected two countries, since this is considered a crucial point in treatment of national minorities in sovereign states.

\footnotetext{
${ }^{3}$ Peter Horváth and Jaroslav Mihálik, "SMER-SD and FIDESZ: The National Interests and Populism in the 2010 Parliamentary Elections," Innovative Issues and Approaches in Social Sciences 2 (2011).

${ }_{4}$ Natalija Schleinstein, Dagmar Sucker, Agnieszka Wenninger, and Anja Wilde, Roma in Central and Eastern Europe, Thematic Series 2009/02: Social Sciences Eastern Europe (GESIS Leibniz Institute for the Social Sciences, 2009).

${ }^{5}$ Monika Flašíková-Beňová, Hannes Swoboda, and Jan Marinus Wiersma, Roma: A European Minority. The Challenge of Diversity (European Union: Group of the Progressive Alliance of Socialists and Democrats in the European Parliament, 2011).

${ }^{6}$ European Union Agency for Fundamental Rights, The Situation of Roma in 11 EU Member States: Survey Results at a Glance (Luxembourg: Publications Office of the European Union, 2012).

7 Aidan McGarry, Who Speaks for Roma? Political Representation of a Transnational Minority Community (New York: Continuum, 2010).
} 
Second, the article examines the roots and sources of new wave nationalism, which may be described as anti-Roma positions and negativism. In the third part of the paper we use sample quotations from the individual in-depth interviews with young respondents from two research locations in Slovakia to interpret our arguments. The data collection and analysis was performed within international collaborative project MYPLACE (Memory, Youth, Political Legacy and Civic Engagement). The fieldwork was conducted during late 2012.

The paper has no aim to solve the issue of nationalism in Central Europe. However, derived from the analysis and current situation in both states, the focus is on explaining the reasons of the changing status quo. A critical part of this change is the denial of nationalism related to interstate conflict, and gaining support of the common citizenry for the parties and movements who emphasize ethnic nationalism against one specific group of inhabitants.

Therefore, the article argues that support for traditional national parties and movements continues to diminish and the new wave of right-wing extremism continues to spread across the region, which can be demonstrated through the popular support of political leaders who gain their political power through antiRoma campaigning.

\section{MINORITY POLICY-MAKING IN HUNGARY AND SLOVAKIA}

In this part of the paper, we discuss the national perspective of minority policymaking in the two states that have shared a common history for several centuries during the existence of the Hungarian Kingdom and later the Austrian-Hungarian Monarchy.

In this retrospective approach, Hungary is considered a country that codified the collective rights of minorities even earlier than the other countries of the region. Formulation of the requirements for the minority groups living in Hungary was acknowledged already in the second half of the $80 \mathrm{~s}$. This period was characteristic due to the economic and political transformation caused by the society changes in the whole Central Eastern Europe. Hungary witnessed systematic changes still in the $70 \mathrm{~s}$ in relation to the status and position of the ethnic groups. ${ }^{8}$ The article discusses the mistreatment of Hungarian minorities which began in the second half of the 70s. From this perspective, Hungary is considered unique, since the open minority policy during the Soviet times was determined a threat to the unity of Soviet republics and a support for irredentism. In the Hungarian perspective this

\footnotetext{
8 Csaba Szaló, "Národnostní politika $\vee$ Mad’arsku: realita a vize samosprávy menšin"; in: Břetislav Dančák and Petr Fiala, eds., Národnostní politika v postkomunistických zemích (Brno: Masarykova univerzita, 2000).
} 
situation can be explained as a consequence of historical multi-ethnic Hungary and the politics of transnationalism as well as struggle for dominant position of Hungary in Central Europe. The key role lies in introducing the new legislation on free assembly of the minority members during the years 1988 and 1989 . Followed by the constitutional amendment in October 1989, minorities acquired the right to exercise their own culture, religion, and most importantly the right to use their mother tongue. In 1990, the Hungarian constitution declared that the minorities living on its territory create inevitable part of the state. In other words, the position of a titular citizen shall be granted to all members of ethnic groups that:

1) have lived in the territory of Hungary at least for one century;

2) members of the ethnic group possess the Hungarian citizenship;

3) the difference from other citizens is distinguished by language, culture, identity and active form of solidarity which leads to preserve those differences. ${ }^{9}$

In the very same Constitutional paragraph the political representation of national minorities was guaranteed by the constitutional act. Upon this decision the minorities shall obtain the rights to create local and national self-governments. The new Constitution created new institutions as well, the Office for Ethnic and National Minorities and an Ombudsman for minority rights, whose competences shall be vested in helping to solve the issues and relations among citizens if there is case of violation of law. Hungary had become one of the few European countries that created specialized institutions to protect its national minorities. The first Ombudsman was designated in 1995 and acted as an institution independent of executive or judiciary power. However, it has the duty to inform the Hungarian Parliament about its acts.

The formerly established Office for Ethnic and National Minorities, which was essentially built as an independent body, was transformed into the Ministry for National and Ethnic minorities within the Prime Minister's Office of Hungary in 2007. All the changes applied in the legal norms declared the Hungarian position in adopting the historical continuity of cultural differentiation that practically stressed the settlements of culturally different ethnic groups in today Hungary. The aim of this policy was to offer and guarantee the specific rights of the groups of citizen that were identified on the basis of different cultural characteristics.

We can then declare that the focus on differentiating the citizens' ethnicity was completely different, as in the case of Soviet principle of minority assimilation. Already in 1989 the request of assimilation was substituted by the opposite perspective - instead of neglecting the use of the minority languages toward protection and active use of the minority tongue. The applied changes have settled

\footnotetext{
${ }^{9}$ Ibid: $174-175$.
} 
a milestone in the process of complex legislation acts that was later defined in the Law on rights of national and ethnic minorities in 1993.

Although the minority acts in Hungary introduced the right for minorities to create political representation in the local and national self-governments, there are significant absences in national level representation in the Parliament. The adopted law practically did not comment this kind of representation, since the acquired legal system acknowledged the permanent minority representation, which could not be achieved due to the minority representation already at the local level. This factor remained unsolved and problematic during the system transformation in the $90 \mathrm{~s}$ and following the up- to-date structure of the Hungarian parliament we cannot talk about the adequate nondiscrimination strategies from the perspective of proportional representation. The law from 1993 defined the existence of 13 minorities in Hungary (Table 1 ).

Table 1. The minority groups in Hungary according to the 2001 census $^{10}$

\begin{tabular}{|c|c|c|}
\hline Minority group & Total & 1,9 \\
\hline Roma & 190,046 & 0,6 \\
\hline Germans & 62,233 & 0,17 \\
\hline Slovaks & 17,693 & 0,15 \\
\hline Croats & 15,620 & $\mathrm{x}$ \\
\hline Romanians & 7,995 & $\mathrm{x}$ \\
\hline Ukrainians & 5,070 & $\mathrm{x}$ \\
\hline Serbs & 3,816 & $\mathrm{x}$ \\
\hline Slovenes & 3,040 & $\mathrm{x}$ \\
\hline Poles & 2,962 & $\mathrm{x}$ \\
\hline Greeks & 2,509 & $\mathrm{x}$ \\
\hline Bulgarians & 1,358 & $\mathrm{x}$ \\
\hline Ruthenians & 1,098 & $\mathrm{x}$ \\
\hline Armenians & 620 & \\
\hline
\end{tabular}

All of the above-mentioned minorities are legally recognized and obliged to found and organize minority self-governments. The law that prohibits assimilation, discrimination, and harassment, guarantees the creation of school classes if there are more than eight pupils who speaking a minority language. Nevertheless, the estimated number of Roma minority is somewhere between 500,000 and $800,000 .{ }^{11}$

\footnotetext{
${ }^{10}$ World Directory of Minorities and Indigenous Peoples, "Hungary Overview" // http://www. minorityrights.org/?lid=5804\# (accessed March 11, 2013).

${ }^{11}$ Immigration and Refugee Board of Canada, "Roma in Hungary" (March 1998) //
} 
The state is also required to support cultural activities of minorities and local governments need to facilitate the availability of official documents in minority languages. In regions inhabited by minorities there should be available bilingual street names and institutions. The Hungarian minority act became the target of criticism from several points of disagreement. This was particularly the ambiguously worded conditions of use of minority languages broadcast by state television and radio, and the refusal to allow the complete execution of state functions to the minority government. There is also a problem in areas where the majority of the population is members of minorities; the government can usurp the functions and powers of the municipal council and local authorities. In these cases there was a lack of resources for effective management in areas that government should implement. The government addressed this situation by issuing a decree in 2006, when the buildings and offices that use the government since 1995, have been transferred to their property through a single transmission. Critics also note the electoral system in minority governments, since the legislation allowed the participation in elections of all residents, and the system is not bound by belonging to a minority group. Thus, there was representation of those people who almost did not belong to the relevant minority. This situation can be explained pragmatically governments are the executor of public interest; thus they have public financial and non-financial resources. There was also a situation in which agents tried to illegally enter the Roma self-government to deliberately disadvantage and segregate people belonging to this ethnic group.

These problems have been addressed by amendments to the original Act of 1993. The Hungarian National Assembly adopted comprehensive changes to minority law in 2005. These updated the organizational structure of minority government between the local and national level by creating regional representation for minorities and specified their powers. The abuse of the electoral system to minority councils was amended in Article 70 of the Hungarian Constitution of $2002^{12}$, which clearly stipulates that only voters belonging to an ethnic group can participate at the elections to the local governments; the same condition is effective for candidates to minority governments. Under this framework, candidates for election to the minority government had to declare their ethnic identity to the district election committee chairmanship. On the basis of the changes, elections were held in October 2006 and a total of 2,045 minority governments were elected. All thirteen recognized ethnic and national minorities

http://www.unhcr.org/refworld/docid/3ae6a823c.html (accessed March 16, 2013); "Romani in Hungary," European Commission (October 2006) // http://ec.europa.eu/languages/euromosaic/hu3_en.htm (accessed March 11, 2013).

12 The Law came into effect upon the accession to the European Union in May 2004. 
elected their own representations. More than a half of the total number of representations, 1118, were dedicated to the Roma minority. Despite numerous positive modifications of the Act and the Electoral Institute, not all minorities have declared satisfaction with the new system. In particular, representatives of the Ukrainian minority government pointed to the fact that about $1 / 3$ of their representation is not of Ukrainian minority candidates. However, statistics show that minorities got a lot of votes of "sympathy"; for example, the Armenian minority government would not have even drawn up without it. ${ }^{13}$ This can be demonstrated as an imperfect condition for registration of candidates and authentication method of ethnicity. Therefore, the current legislation is going to be updated in this sense for practical reasons.

In considering the application of the European dimension of a policy of nondiscrimination against ethnic minorities living on the territory of sovereign nation states, we should mention the 2003 Act on equal treatment and equal opportunities for minorities. This generally prohibits discrimination in a total of nineteen areas: sex, race, skin color, nationality, national or ethnic background, language, physical or mental disability, health, religion, political beliefs, marital status, sexual orientation, gender identity, age, social origin, property relations, conditions of employment, membership in interest (trade) organization or any other similar activity and situation. ${ }^{14}$

The law covers these forms of discrimination-direct and indirect, harassment, unlawful segregation, and persecution. However, affirmative action under the Act is not considered a violation of the legal framework.

The most complicated was the issue of Roma integration. In 2005, under the Act on Equal Treatment, employers disregarded the legislation about discriminating against the citizens of Roma origin in nine reported cases. For this reason, Hungary created a stricter framework for positive discrimination of the Roma minority, not only in employment but also in education and housing, which often confronts the social tolerance of the majority.

In 2004, a referendum was held in Hungary, which was intended to enable the acquisition of Hungarian citizenship to ethnic Hungarians living outside the kin state. The referendum was invalid because of low voter turnout. The Hungarian

\footnotetext{
13 Klaudia Lászlóová, "Menšinové samosprávy v Mad'arsku," SME (October 1998) // http://www.sme.sk/c/2168718/mensinove-samospravy-v-madarsku.html (accessed March 12, 2013). ${ }^{14}$ Act CXXV of 2003 on Equal Treatment and Promotion of Equal Opportunities // http://www.egyenlobanasmod.hu/data/SZMM094B.pdf (accessed February 27, 2013).
} 
government, however, revitalized the efforts and allowing foreign Hungarians to apply for dual citizenship during the current legislative period. ${ }^{15}$

In the election in 2006, Hungary was the subject of various anti-government protesters and riots, and in 2007 increased steadily worrying trend of success and support for paramilitary civil movements and ultra-right political groupings as the Hungarian Guard or Jobbik movement and whose public manifestations include various anti-Roma declarations. ${ }^{16}$ Even the European Commission against Racism and Intolerance ${ }^{17}$ confirmed in 2008 that Hungary had sharply increased racism in public and political life. The Committee noted the frequent racism and social intolerance towards minorities through public media and on the Internet. During this period direct physical attacks on Roma citizens also expanded, especially in rural areas where Roma communities are mostly concentrated.

The parliamentary elections in 2010 and 2014 were marked by a clear victory of right-wing Fidesz, led by Viktor Orbán, quietly supported by anti-Semitic and anti-Roma Jobbik Movement and the Movement for a Better Hungary. The formation comfortably gained constitutional majority in the national parliament. One of the first actions of the new government on minorities was already mentioned amendment to the law on citizenship. The Act was adopted almost unanimously and came into force on January $1^{\text {st }} 2011$, allowing foreign ethnic Hungarians to apply for dual citizenship-the controversial law sparked a wave of furious debates at the European level and especially in Slovakia, where there is approximately a half-million ethnic Hungarians.

The Prime Minister of Slovakia, Robert Fico, yet in 2010, described the drafted law as the security threat to Slovakia and the Slovak Parliament adopted countermeasures in terms of loss of Slovak citizenship for people who get Hungarian dual citizenship. For comparison, Romania, where there is a relatively large Hungarian minority population, has not acceded to any restrictive measures.

Future minority policy and non-discrimination of persons belonging to ethnic minorities was crucial to the Hungarian EU Presidency in 2011, when it adopted a European framework for national integration strategies of Roma. Based on this commitment of EU, the Member States are required to develop national strategies for Roma integration and implement them in real social practice. It remains a question, however, to what extent it will be possible to implement the action

\footnotetext{
15 Rainer Bauböck, "Dual Citizenship for Transborder Minorities? How to Respond to the Hungarian Slovak Tit-for-Tat," EUI Working Papers (Robert Schuman Centre for Advanced Studies) 2010/75 // http://cadmus.eui.eu/bitstream/handle/1814/14625/RSCAS_2010_75.corr.pdf?sequence=3.

16 Miroslav Mareš, "The Extreme Right in Eastern Europe and Territorial Issues," Central European Political Studies Review Part 2-3, Vol. 11 (2009): 82-106 // http://www.cepsr.com/clanek.php?ID=367.

17 No author named, "ECRI Report on Hungary," European Commission Against Racism and Intolerance (February, 2009) // http://www.coe.int/t/dghl/monitoring/ecri/country-by-country/hungary/HUN-CbCIV-2009-003-ENG.pdf (accessed March 14, 2013).
} 
program in Hungary due to the rise of nationalist and anti-Semitic conflicts in society, and especially in Europe, where around 10 million people of Roma origin exist.

In the case of the independent Slovak Republic, we can talk about the greatest percentage of minority population out of all V4 countries. According to the numbers expressed in percentages based on the censuses in Slovakia since 1991, we confirm the existence of multiple minority populations, particularly the Hungarian and Roma (Table 2). At present, the Hungarian minority represents about $8.5 \%$ of the Slovak population which, in absolute numbers corresponds to 458,467 inhabitants of Hungarian nationality. On closer examination of the Slovak ethnic composition of the population, we find that the Roma minority, unlike most numerous ethnic Hungarians, recorded an upward trend, and therefore currently constitutes about $2 \%$ of the total population. Slovakia is a country that is made up of traditional ethnic groups; this means that their presence is due to the ethnic composition of the state formations, which included the territory of present-day Slovakia in the past and minorities on its territory organized for decades and centuries. These include also the Czech, Rusyn, Ukrainian, German, Polish, Croatian, Serbian, Russian, Bulgarian and Jewish minorities.

Table 2. Ethnic structure of Slovakia based on 1991, 2001, 2011 census $^{18}$

\begin{tabular}{|c|c|c|c|c|c|c|}
\hline \multirow{2}{*}{$\begin{array}{c}\text { Living inhabitants } \\
\text { permanent residence) }\end{array}$} & \multicolumn{2}{|c|}{2011} & \multicolumn{2}{c|}{2001} & \multicolumn{2}{c|}{1991} \\
\cline { 2 - 7 } & abs. & $\%$ & abs. & $\%$ & abs. & $\%$ \\
\cline { 2 - 7 } & 5397036 & 100,0 & 5379455 & 100,0 & 5274335 & 100,0 \\
\hline Nationality & & & & & & \\
\hline Slovak & 4352775 & 80,7 & 4614854 & 85,8 & 4519328 & 85,7 \\
\hline Hungarian & 458467 & 8,5 & 520528 & 9,7 & 567296 & 10,8 \\
\hline Roma & 105738 & 2,0 & 89920 & 1,7 & 75802 & 1,4 \\
\hline Czech & 30367 & 0,6 & 44620 & 0,8 & 52884 & 1,0 \\
\hline Ruthenian & 33482 & 0,6 & 24201 & 0,4 & 17197 & 0,3 \\
\hline Ukrainian & 7430 & 0,1 & 10814 & 0,2 & 13281 & 0,3 \\
\hline German & 4690 & 0,1 & 5405 & 0,1 & 5414 & 0,1 \\
\hline Polish & 3084 & 0,1 & 2602 & 0,0 & 2659 & 0,1 \\
\hline Croatian & 1022 & 0,0 & 890 & 0,0 & $x$ & $x$ \\
\hline Serbian & 698 & 0,0 & 434 & 0,0 & $x$ & $x$ \\
\hline Russian & 1997 & 0,0 & 1590 & 0,0 & 1389 & 0,0 \\
\hline Jewish & 631 & 0,0 & 218 & 0,0 & 134 & 0,0 \\
\hline Moravian & 3286 & 0,1 & 2348 & 0,0 & 6037 & 0,1 \\
\hline Bulgarian & 1051 & 0,0 & 1179 & 0,0 & 1400 & 0,0 \\
\hline Other & 9825 & 0,2 & 5350 & 0,1 & 2732 & 0,1 \\
\hline Uknown & 382493 & 7,0 & 54502 & 1,0 & 8782 & 0,2 \\
\hline
\end{tabular}

$x$ - record is not possible from logical reasons

18 Statistical Office of Slovakia, "Citizens' Census of 2011, 2001, 1991" // http://portal.statistics.sk/files/tab-10.pdf (accessed February 10, 2013). 
Perhaps the most important framework for the protection of national minorities in the Slovak Republic was the adoption of the Constitution in 1992. Although the preamble itself anchors the national character and the only titular people are considered Slovaks, which gave rise to opposition to the adoption of the Constitution, in particular representatives of the Hungarian opposition party, the Slovak Republic undertook a European framework for the protection of human rights and freedoms. The implication was that international agreements and treaties relating to human rights and freedoms take precedence over domestic legislation, to provide a broader scope of rights. ${ }^{19}$ According to Article 12 of the Constitution, all people in Slovakia are free and equal in dignity and rights. Fundamental rights and freedoms are inalienable, and unchallengeable. Fundamental rights and freedoms are guaranteed in the Slovak Republic to everyone regardless of sex, race, color, language, belief and religion, political or other opinion, national or social origin, nationality or ethnic origin, property, birth or other position. No one shall be for the following reasons preferred or discriminated against. This article even specified the discretion of their nationality and prohibits any influence on this decision and any form of pressure aimed at denationalization. ${ }^{20}$

The Constitution provides for the Slovak language as the only official language in this context; the use of other languages in official communications is expressed in subsequent law. It should be noted that this clause has become perhaps the most problematic in relation to the status of the Hungarian language. Even the Charter of Fundamental Rights and Freedoms adopted by the Czechoslovak Federal Assembly in January 1991 prohibited all forms of discrimination and strengthened the demand for the right to education in their mother tongue. These aspects are also reflected in the original version of the Slovak Constitution of 1992. As a result of populist and nationalist-oriented government policies of Vladimír Mečiar and fears of civil and territorial irredentism in Slovak politics began to appear discriminatory amendments especially in the language law. Despite the broad constitutional guarantees it seemed almost impossible to ensure equitable use of minority languages in official communication. In the first half of the $90 \mathrm{~s}$ two important standards were adopted, namely the use of names and surnames in the minority language ${ }^{21}$ and bilingual labeling of the municipalities where the minority population exceeds $20 \%$ of the population. ${ }^{22}$

\footnotetext{
19 Dušan Labuda, "Jazykové práva národnostných menšín v Československej republike": 128; in: Jana Šutajová and Mária Durkovská, eds., Mad'arská menšina na Slovensku v procesoch transformácie po roku 1989 (Identita a politika II) (Prešov: Universum, 2008).

20 Constitution of the Slovak Republic (September 1992) // http://www.nrsr.sk/web/Static/skSK/NRSR/Doc/zd_ustava_2012.pdf (accessed March 18, 2013).

21 The Law on Registry Office in Slovakia, Collection of Laws (1994, no. 154).

22 The Law on Labelling in Minority Languages in Slovakia, Collection of Laws (1994, no. 191). See also Jaroslav Mihálik and Juraj Marušiak, "The dynamics of Slovak-Hungarian relations - the shift from
} 
In 1995 another amendment to the original law on the use of language in 1990 was adopted and a much stricter definition given that the Slovak language takes precedence over other languages and this is an obligation for the state to create the educational, scientific and information systems in such conditions that each citizen shall acquire and use the state language as spoken and written. ${ }^{23}$ The reaction of a radically oriented wing of Hungarian opposition parties led by Miklós Duray likened the law to cultural fascism: "murderous attacks against the Magyar language and culture in Slovakia is cultural fascism, organized destruction of what took place in Nazi death camps". And further: "Our ultimate goal is political and economic autonomy and total territorial autonomy". He also warned the Hungarian minority not to marry Slovak women, because it will "taint Hungarian race". ${ }^{24}$

The Act sharpened the relations between the governing coalition and representatives of minorities; it has also been criticized as a violation of the commitments of the Slovak Republic in terms of meeting the Copenhagen criteria in the pre-accession negotiations for the EU membership. In 1998 there was a denial of the power and influence of Vladimír Mečiar and center-right parties with SDL and SMK introduced the language act in order to meet the requirements of the European institutions and strengthens the position of minority languages in public life. The new Slovak government was aware that the negative relations between minorities and the majority population do not benefit the society and European integration itself as one of the priorities of the government in the late $90 \mathrm{~s}$. Therefore, the Government established the Council for National Minorities and Ethnic Groups, a government advisory body composed of members of government and representatives of the minorities for various associations, societies and associations such as Hungarian social and cultural association in Slovakia (CSEMADOK), Cultural Association of Roma nationality in Košice, Jewish Cultural Association of Slovak citizens, etc. Following adoption of the law on the use of minority languages in $1999^{25}$ confirmed the wish of a new government on legal guarantees for the use of minority languages, particularly ethnic Hungarians but also Roma, Ruthenians, Ukrainians, Croats and Germans in local councils and municipalities where the minority share of the population represents more than $20 \%$ of the total population. Implementation of the Act revealed real weaknesses in public administration, as employees of the authorities did not know the languages

language issues to legal and symbolic questions," Baltic Journal of Law and Politics Vol. 7, No. 1 (2014): 138 // DOI: 10.2478/bjlp-2014-0008.

${ }^{23}$ The Law on State Language in Slovakia, Collection of Laws (1995, no. 270).

24 Blažena Krivošíková, "Slovenský 'nacionalizmus' a mad’arská hysteria," Prečo? Týždenník literatúry faktu // http://www.chelemendik.sk/docpreco.php?d=00000198 (accessed January 5, 2013).

25 The Law on Use of Languages of National Minorities, Collection of Laws (1999, no. 184). 
of minorities and thus the practical application of the law could not be provided in this regard.

The Slovak Republic adopted a new law on equal treatment in certain areas and protection against discrimination, amending and supplementing certain laws also known as the Anti-Discrimination Act in 2004. ${ }^{26}$ It is the law in accordance with the directives of the European Commission, which regulates the application of the principle of equal treatment and provides means of legal protection if there is a violation of this principle. Respect for the principle of equal treatment is based on the prohibition of discrimination on grounds of sex, religion or belief, race, nationality or ethnic origin, disability, age, sexual orientation, marital status, family status, color, language, political or other opinion, national or social origin, property, birth or other status. The law, among other things, allowed the Slovak National Centre for Human Rights, created in 1993 by the UN project to implement and support the modern system of human rights protection in the Slovak Republic, to represent people who have been subject to discriminatory practices of the above reasons. National legislation in 2002 also expanded the learning opportunities for teachers whose teaching is in the minority language. In the same vein and in the spirit of the implementation of constitutional guarantees for citizens and their rights to education in their mother tongue and to the fulfillment of the EU pre-accession criteria, the University of János Selye was established in Komárno. This university is the first educational institution of its kind, with the dominant teaching in Hungarian language. It opened its gates to students in January 2004. The Government strongly supported the issuance of newspapers and magazines in minority languages and various other cultural activities at that time. ${ }^{27}$

A significant step backwards in relations not only between citizens and Slovak national minorities in Slovakia, but also in bilateral relations between Hungary and Slovakia, was the formation of the governing coalition after the parliamentary elections in 2006. Three-party coalition Smer-SD, SNS and HZDS failed to overcome a historic reconciliation between two neighboring countries and came to a number of bilateral conflicts on both sides of the Danube River. The most notable case was manifested by the issue of a student of Hungarian ethnicity who was beaten-Hedviga Malinová in 2006; a year later a paramilitary organization in Hungary, the Hungarian Guard, was founded and, during the same year the National Council of the Slovak Republic declared the inviolability of the Beneš Decrees. Another source of political nationalism was the controversial police action during football match against the group of fans in Dunajská Streda. Then, National

\footnotetext{
${ }^{26}$ The Law on Anti-discrimination in Slovakia, Collection of Laws (2004, no. 365).

27 Gábor Lelkes and Károly Tóth, Národnostné a etnické menšiny na Slovensku 2006 (Šamorín: Fórum inštitút pre výskum menšín, 2008), p. 131-342.
} 
Council approved a number of laws related to minorities in 2009 - an amendment to the Education Act, which governs the use of geographical names in textbooks for ethnic minorities, further amendment to the State Language Act, which reestablishes penalties and fines for violations of the Act. The culmination of tensions between the two countries peaked in banning the Hungarian President László Sólyom from entering the Slovak Republic; Sólyom wanted to officially unveil the statue of Hungarian King Stephen during a visit to Komárno.

The cabinet of Iveta Radičová significantly revised the language law after the parliamentary elections in 2010. In practical terms the goal was to reduce the fines for violating the law. The government of central-right parties also revised the Law on use of the languages of national and ethnic minorities and the current 20 percent limit to use the minority languages in the regions will drop to 15 percent, but this figure must be confirmed in two consecutive censuses of population, which changes the validity of that decision to 2021. Reducing limits to 15 percent, however, affects those municipalities that are already on the list of multilingual by government regulations and there is a minority of at least 20 percent. These can drop off the list only if after three consecutive censuses the number of minority population decrease to less than 15 percent, so the earliest possible change will be in 2031.

The development of minority policy and bilateral relations between the Slovak Republic and Hungary are largely a reflection of nationally oriented populist governments in both countries. In addition, some modifications are not very successful-e.g. the Language Act, or the use of minority languages. An emerging policy of transnationalism in current Hungarian government involves severe fears in Slovakia, as well as in Romania.

Equally important is the role of the social inclusion of Roma into mainstream society. For this reason, the present Slovak government has adopted a Strategy of the Slovak Republic for Roma integration in 2020. The aim of this strategy is the need to respond to the challenges of social inclusion of Roma communities. Increasing extreme poverty and systematic social decline of local communities of most marginalized Roma communities since 1989 highlights the need to change the approach of public policies in this area. This strategy is based on the need to shift from passive welfare state and municipal authorities towards energizing support. The issue of integration of Roma communities in Slovakia went beyond national policy and has become one of the key points of social policy and social inclusion. 


\section{THE SOURCES OF NATIONALISM AGAINST ROMA IN SLOVAKIA AND}

\section{HUNGARY}

The social, ethnic and political discourse on Roma in Central Europe is basically associated with the problematic ways of social and political integration in a majoritarian society. Usually, the political actors, journalists, as well as analysts, wrap these issues around the so-called Roma question or Roma issues.

Representatives of Roma communities usually disagree with such labeling, since it involves discriminatory tendencies against the ethnic group. Likewise, the titular citizens refer to such ethnic discourse as social exclusion compared to issues of minority integration.

Slovak society is differentiated with regard to ethnic and cultural composition; therefore we assume that these inequalities and diversity provide for cultural and ethnic heterogeneity. ${ }^{28}$ The assumption is that the major source of ethnonationalism in Slovakia against the Roma population is caused by social inequality, state support and the application of the social reform. The other argument is the lifestyle and diverse cultural approach of the Roma communities in such aspects as housing, education, health care, poverty and employment measures.

The very same can be transformed into the emergence of a vivid wave of nationalism in Hungary. It could be seen in newspapers and journals that between 2009 and 2013, multiple anti-Roma demonstrations were organized in Hungarian cities and regions. ${ }^{29}$ Evenly, there is a strong support of the anti-Roma rhetoric between the politicians of the ruling party Fidesz. One of the founding members declared that "a significant part of the Roma are unfit for co-existence. They are not fit to live among people. These Roma are animals and they behave like animals". 30

Overall, the Roma discourse is a significant part of the strategic social integration model of the countries. Speaking from the point of view of the labour market, Roma are generally over=represented among the long-term unemployment and more likely dependent on the social welfare system which causes a great challenge for the social inequality. Again, these are consequences of raising antiRoma nationalism in both countries. According to Martin Kovats, the costs of

\footnotetext{
28 Peter Drál, "Lenivost' ako „esencia" rómskej etnickej identity: kritická analýza diskurzu slovenskej sociálnej politiky"; in: Findor "Drál', Ako skúmat' národ. Devät' štúdií o etnicite a nacionalizme (Brno: Tribun, 2009).

${ }^{29}$ Ivana Kottasová, "Jobbik's Anti-Roma Crusade," Presseurop (June 2009) // http://www.presseurop.eu/en/content/article/28071-jobbiks-anti-roma-crusade (accessed March 8, 2013); Nick Thorpe, "March by Far Right Raises Concern for Hungary's Roma," bbc.co.uk (October 2012) // http://www.bbc.co.uk/news/world-europe-19992263 (accessed March 19, 2013); Marton Dunai, "Thousands rally in anti and pro Roma marches in Hungary," National Post (October 2012) // http://news.nationalpost.com/2012/10/17/thousands-rally-in-anti-and-pro-roma-marches-in-hungary/ (accessed March 19, 2013).

30 "Anger Grows in Hungary over Anti-Roma Article," guardian.co.uk (January 2013) // http://www.guardian.co.uk/world/2013/jan/08/anger-hungary-anti-roma-article (accessed March 18, 2013).
} 
improving these people's living conditions and of returning their labour to profitability provides a strong incentive for the state to define Roma people as a distinct community, thereby allowing policy to focus on the far cheaper promotion of ethnic difference. ${ }^{31}$ This might be easily misused by the promoters of nationalism, especially by the nationalist movements and parties, such as Jobbik and Fidesz in Hungary, or Slovak national party (SNS) and L'S-Naše Slovensko (Peoples' Party - Our Slovakia) in Slovakia.

A huge role has been played by the political delineation of Roma as a group which majority and the mass society recognize within the politics of increasingly fragmented and demanding minority population. As Kovats continues, the essential difference between Roma people and everyone else in the society exploits traditional prejudices and low expectations. Difference is a shared word to define social disproportion, social conflicts, migration, and perhaps, most notably the failure of the social and political integration of the Roma communities. These negatives still conserve the social isolation of Roma and support the ideologies of segregation. ${ }^{32}$

Even the nationalist Slovak National Party, usually known for its antiHungarian proclamation and radicalism in the words of the party leader, Ján Slota, has recently adopted the anti-Roma slogans, which were visible on the billboard campaigns during the early parliamentary elections in 2012. The following picture illustrates the shift from Hungarian threats to nationalism against Roma population (Figures 1 and 2).



Figure 1. Slovak national party campaign 2012: "How long will we pay for gypsies?"33

\footnotetext{
31 Martin Kovats, "The politics of Roma identity: between nationalism and destitution," Open Democracy (July 2003) // http://www.opendemocracy.net/people-migrationeurope/article_1399.jsp (accessed March 18, 2013).

32 Ibid.

33 Slovak National Party Electoral Campaign // http://www.sns.sk/mediatlacove-besedy/p-sns-vmediach/2012-predvolebna-kampan/ (accessed March 18, 2013).
} 


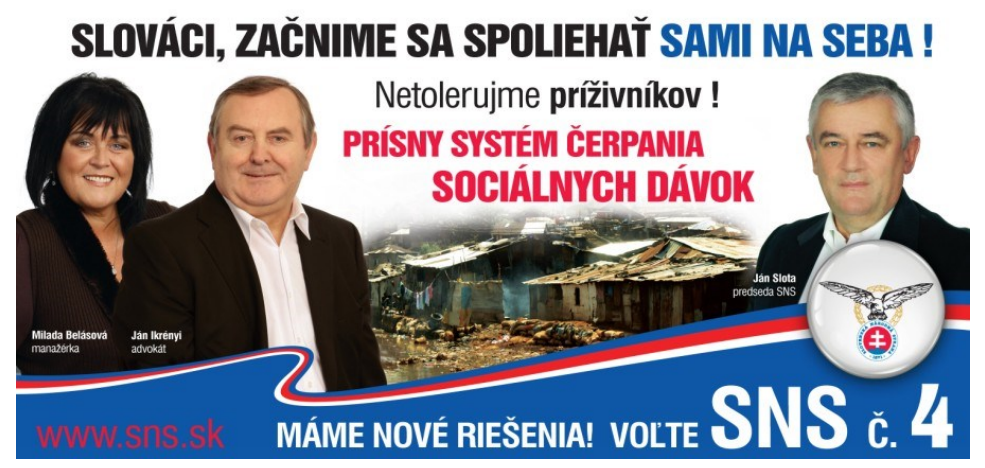

Figure 2. Slovak national party campaign 2012: "Stop supporting the parasites!"34

The SNS played a similar anti-Roma card two years ago. In 2010 they used a billboard depicting a half-dressed, obese Roma man with the slogan: "Stop feeding those who do not want to work!" The party was charged with running a discriminatory and racist campaign, so the party had to cover the billboards (Figure 3).

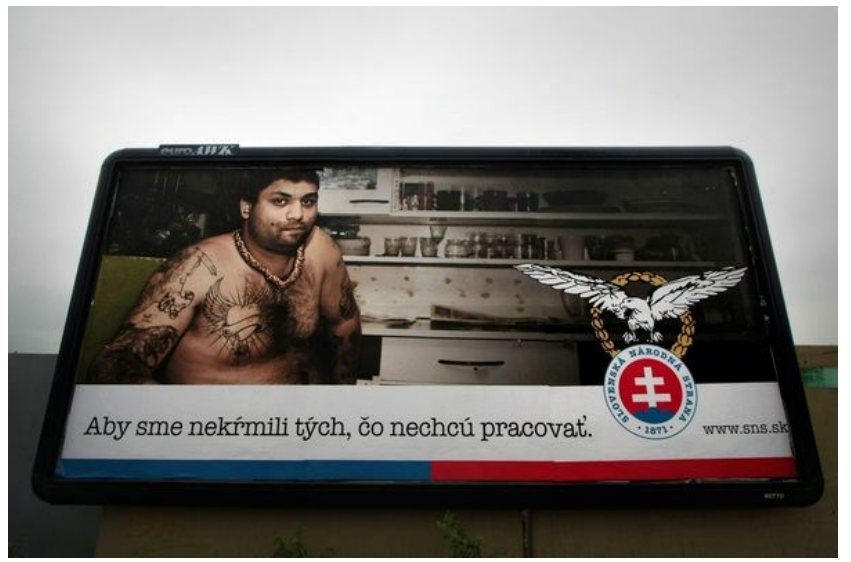

Figure 3. Slovak national party campaign 2010: "Stop feeding those who do not want to work!"

In addition to its anti-Roma campaign, the nationalist SNS is also using slogans blasting neighbouring Hungary, a country that is itself led by nationalist conservatives. "We've been defending Slovak land for 140 years. Orbán's boat is sinking", is the SNS message, which picks out Hungary's economic problems under the leadership of Prime Minister Viktor Orbán. ${ }^{35}$ SNS leader, Ján Slota, is also known for anti-Hungarian rhetoric; he is also claiming that Budapest has not yet abandoned the idea of establishing and reviving the "Great Hungary". In other

${ }^{34}$ Ibid.

35 No author named, "Slovak nationalists incite anti-Roma hatred," hopenothate.org.uk (February 2012)

// http://www.hopenothate.org.uk/international/article/55/slovak-nationalists-incite-anti-roma-hatred (accessed March 18, 2013). 
words, Ján Slota is establishing a policy of fear of the secession of the southern parts of Slovakia.

There has been a continuous regression of support for nationalists recorded since 2010 . The Slovak national party gained only $5,1 \%$ of the valid votes in 2010 compared to $11,7 \%$ in 2006 . The electoral year 2012 was significant in the manner that it was the first time when Slovak national party did not even enter the threshold of the parliament ( $4,55 \%$ votes). The general reasons might be observed as fading of the ethnic agenda in 2010, even considering the peak of the ethnic tensions between Hungary and Slovakia. Here we must consider that rhetorically and even combined in the program, the strongest political party in Slovakia, SMERSD, took a majority of the SNS voters. ${ }^{36}$

There is another reason for the ethnic immobilization as well. Since the government coalition after 2010 election was created by pro-reformist and central right parties there was absenting the grievance and political will to do ethnic politics based on the external enemy agenda. During the term of Iveta Radičová government we can talk about a potential for national populism that might be mobilized any time now. Ever since, the shift from an external enemy has shrunk to the internal problem of Roma segregation and potentials of integration.

As for the final failure of the Slovak national party in 2012, we can follow several arguments. The above-mentioned one is particularly true when considering the fact that the former SNS voters gave their votes to different parties such as SMER-SD or newly established parties, some of them nationalists, such as L'S-Naše Slovensko, which is a political fracture of well-known and banned organization Slovenská pospolitost'. The party as well as the mother organization is strictly focused on spreading hatred against Jews and Roma and developing the conspiracies and repression. The majority of their arguments offer "universal and final" solutions for the economic perspective as well as the ethnic dimension. The party elaborated their program into 10 major points that cover areas such as employment, civic and legal equality, country self-sustainability, ethnic nationalism, euroscepticism, etc.

Topic number one for them is the Roma question. The party has its bastion in the eastern part of Slovakia, where the Roma ethnic conflict escalated during the several few years. The members of the party claim to stand the guard with the Slovak citizens against the Roma "parasites".

Unlike some other parties, L'S-Naše Slovensko may consider its electoral result in 2012 not only relatively successful, but, to some extent, even promising.

36 Ol'ga Gyarfášová, "Slovenské parlamentné volby 2010: nacionálna agenda na ústupe?" Central European Political Studies Review Part 1, Vol. 13 (Winter 2011) // http://www.cepsr.com/clanek.php?ID=432_(accessed March 18, 2013). 
'S-Naše Slovensko is one of the parties which managed to improve their electoral results for the second consecutive elections. While in 2010, when the party ran in parliamentary elections independently for the first time, it gained $1.33 \%$ of the vote (it was supported by 33,724 voters), and $1.58 \%$ in 2012 which stands for 40,460 voters. ${ }^{37}$ Following the regional elections in 2013, the leader of the party Marian Kotleba gained $55,5 \%$ of popular votes which enabled him to be the president of Banska Bystrica region.

This trend is significant and visible also in Hungary. While the leading party of Viktor Orbán-Fidesz-is enjoying mass support (even though it lost approximately half of the supporters), ${ }^{38}$ the second place is taken by Jobbik, which substituted for the established socialist party. From the perspective of Slovakia, Fidesz is also considered a nationalist party, since its policy making and implications show the focus on national issues, strengthening the position of Hungary in V4 perspective, the policy of dual citizenship and transnationalism.

In general, Jobbik is considered the most radical Hungarian political party. With its 47 seats in parliament, the party claims to be a eurosceptic, nationally oriented party that emphasizes the national sovereignty and the citizens' guarantees. Behind such vague descriptions, one can occasionally find antiSemitism, racism, and homophobia. In comparison to Fidesz, Jobbik is purely oriented towards ethnic issues, particularly against the Roma minority, which constitutes the biggest minority in Hungary. The infamous Hungarian guard (Figure 4 ) is also a consequent product of Jobbik's political intervention. It was established in 2007 with 56 first guardians; the leader of Jobbik, Gábor Vona, celebrated the creation of the Guard as a significant step forward in protection of the Hungary in the globalized world.

\footnotetext{
37 Grigorij Mesežnikov, "Slovak Parliamentary Elections 2012: Is Radical Nationalism Rising or on the Decline?" deconspirator.org (June 2012) // http://deconspirator.com/2012/06/13/slovak-parliamentaryelections-2012-is-radical-nationalism-rising-or-on-the-decline/ (accessed March 18, 2013).

38 SITA, "Mad’arská strana Jobbik je podla prieskumu druhá najpopulárnejšia," Pravda (March 2012) // http://spravy.pravda.sk/svet/clanok/242024-madarska-strana-jobbik-je-podla-prieskumu-druhanajpopularnejsia/ (accessed March 18, 2013).
} 


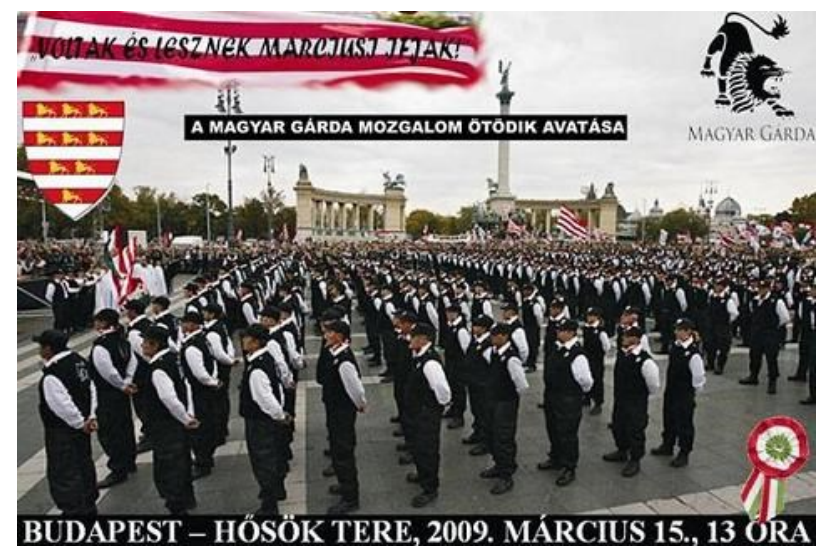

Figure 4. Hungarian guard (an officially banned organization)

\section{RIGHT-WING EXTREMISM AS A NEW FORM OF SOCIAL AND POLITICAL NATIONALISM ${ }^{39}$}

Academic studies show that it is very difficult to study the 'radical right' or extremism in transforming countries, especially in Central and Eastern Europe $(C E E)$, because there is a lack of reliable information on racist extremism in the region. However, there is some evidence that racist extremism in the CEE region (including Slovakia) follows a pattern, organizationally, of small scale mobilization and, substantively, is linked to issues of transition such as corruption, a worsening economic situation, and minority protection or European enlargement. ${ }^{40}$ Extremist tensions in society are also encouraged by an educational system that keeps a strong national and ethnic bias, and reproduces stereotypes in society, especially those regarding minorities. ${ }^{41}$

According to Nociar, ${ }^{42}$ right-wing extremism in Slovakia can be distinguished by two kinds of entities: groups of skinheads and leaderless resistance groups operating unofficially, independent of political parties without a stable organizational structure; and civic organizations and political parties that try to establish permanent structures of institutionalized right-wing extremism. The best known and most successful of the latter type are Slovak Unity (Slovenská Pospolitost') and People's Party-Our Slovakia (L'udová strana-Naše Slovensko).

${ }^{39}$ A substantive part of this chapter is presented in the research report of the MYPLACE project: Jaroslav Mihálik and Peter Horváth, "Deliverable 5.3:Country based reports on interview findings" (November 2013) // http://www.fp7-myplace.eu/documents/D5.3\%20Slovakia.pdf.

${ }^{40}$ Cas Mudde, "Racist Extremism in Central and Eastern Europe," East European Politics and Societies Vol. 19, No. 161 (2005).

41 Zuzana Poláčková, "Nebezpečné stereotypy o postavení mad’arskej menšiny na Slovensku"; in: Jana Šutajová, ed., Mad'arská menšina na Slovensku v procesoch transformácie po roku 1989 (Historické, politologické a právne súvislosti), Volume II (Prešov: Universum, 2008).

42 Tomáš Nociar, "Right-wing extremism in Slovakia," International Policy Analysis (December 2012) // http://library.fes.de/pdf-files/id-moe/09567.pdf (accessed October 23, 2013). 
Nociar goes on to note that, in Slovakia, right-wing extremism emerged directly after the demise of the communist regime in 1989. While in the 1990s, members of the skinhead subculture were the most typical holders of right-wing extremist ideas, since 2003 a crucial change in representation has occurred, and right-wing extremism in Slovakia has become more organized and has developed political aspirations. This is one of the reasons for the organizational diversity of right-wing extremist groups, which operate as:

- political parties;

- $\quad$ civic associations;

- unofficial groups (subcultures or leaderless resistance groups).

Most often, the concept of right-wing extremism is associated with violent demonstrations against people of a different race or ethnicity, or people who are otherwise different. People are often associated with right-wing extremism for denying the democratic functioning of society and its institutions although as an ideology right-wing extremism is not perceived to explicitly deny democratic principles. Moreover right-wing extremists might be individuals or groups that seek violence or ideologist not directly engaged in violence but who promote the principle of inequality of different races and ethnicities (often rooted in an ideology of fascism and tradition of the Slovak state during World War II).

As Nociar observes, in terms of ideology, extremist groups in Slovakia have two main profiles:

- the ultra-nationalist stream-who espouse nationalism, anti-Semitism and anti-Hungarian chauvinism and are apologists for the wartime Slovak State and draw on its legacy;

- $\quad$ the neo-Nazi stream-who are typically racist, anti-Semitic and apologists for the Third Reich. ${ }^{43}$

There are several factors influencing a rise of extremism and populism in society; political and ideological factors often reflect a deeper frustration and hopelessness of people in a poor economic and/or social position.

Some respondents in our research viewed extremist groups as motivated solely by political power; they aimed to attract voters through radical populism. Cziko exemplifies this view: "people get cheated, it is the same as high level politics" (Cziko, Rimavská Sobota). Respondents recognize that people are frustrated by the failure of politicians to solve inequalities, but see extremist solutions as fanatic or sick. Respondents discussed skinhead groups as extremist and racist and stated that they did not approve of them, although often in passing noting that they agreed with some of their ideas: "I agree with them, but I think it 43 Ibid. 
is not correct" (Leila, Rimavská Sobota). Respondents also consider Peoples' PartyOur Slovakia and its leader, Marian Kotleba, to be extremist.

In fact, young people, especially from the south-eastern region of Slovakia, display some sympathy with such extremist parties: they acknowledge that they offer some kind of solution, but say they do not vote for them because these solutions are not correct or real solutions. 'Others' they know-one reference is to friends from the gym-do vote for extremists, however, and agree with such radical measures.

The research conducted suggests that racism is still a widespread phenomenon in Slovakia. One Roma respondent is disgusted that people judge all Roma as the same: "We are not all the same. There are educated and decent people who want to work. But there is no work, so what can they do?" (Beata, Rimavská Sobota).

At the same time, reflecting on the source of this negative stance towards Roma, the respondent characterizes her community in the same way: "because most of us steal, are dirty and rude and this is true" (Beata, Rimavská Sobota). Racial prejudice has become normalized in Slovakian society as is evident from Kristinka's comment below: "... in Slovakia it is normal that people have issues with the Roma. Young people are easy to influence and if they gather around those who are older and who share negative attitudes about Roma they automatically consider it to be true and valid" (Kristinka, Rimavská Sobota).

Offensive comments about the Roma are often repeated within families and respondents point out the way in which the media create an image of all Roma as the same and broadcast only negative news about Roma communities. Thus, respondents consider racism one of the major conflicts in society; it is a long term problem which they struggle to imagine how to address. "All the people are against gypsies. Although, we might be proud of some individuals or Roma that did something positive or try to do something. But I think we are a racist state. I know very few people that would treat Roma positively" (Jana, Trnava).

Opinions vary also on what to do about extremist groups. Libor calls for them to be banned, saying, "I don't understand how an intelligent person can vote for something like Kotleba or Jobbik in Hungary" (Libor, Trnava). Others express real hatred towards extremists: "I completely reject and hate people who judge on racial prejudice, it totally makes me sick" (Nikoletta, Trnava). However, some respondents argue that it would be undemocratic to prohibit extremist organizations or even admit, "I passively support them" (Ivan, Trnava). The most extreme references include that some of Hitler's plans were good. 
Table 3 below explores levels of support for extremist ideas among different age groups in Slovak society. Bieliková observes that there is a growing number of young people who support the ideas of the extreme right. ${ }^{44}$

Table 3. The consent to the ideas of right-wing extremism compared by the age groups

\begin{tabular}{|c|c|c|c|}
\hline Age group & Resistance & $\begin{array}{c}\text { Support for some } \\
\text { ideas }\end{array}$ & Support for all ideas \\
\hline $16-17$ & $8 \%$ & $66 \%$ & $26 \%$ \\
\hline $18-25$ & $17,9 \%$ & $71,8 \%$ & $10,3 \%$ \\
\hline $26-29$ & $8,5 \%$ & $69 \%$ & $22,5 \%$ \\
\hline $30-40$ & $22,7 \%$ & $66,4 \%$ & $10,9 \%$ \\
\hline $40-$ more & $14,9 \%$ & $73,3 \%$ & $11,8 \%$ \\
\hline Total & $15,3 \%$ & $71,2 \%$ & $13,5 \%$ \\
\hline
\end{tabular}

According to the results of her research, views held include those of white supremacy. Youth in Slovakia is at least tolerant of Roma people (39\% said they agreed with the statement that "these people are less valuable than other people"). It is also evident that respondents aged 13-18 years are more tolerant of AfricanAmericans and Asians than of the Roma.

The interviews in both research locations confirmed the general sources of the rise of the extremism in contemporary Slovak society to be: poverty and lack of social inclusion; tension escalated by incorrect and unverified information from some media; the role of family and community in shaping the views of youth.

In general? The desperate situation regarding the Roma issue. People follow the news and they see that gypsies beat up a white guy out of nowhere or that they were given new houses for free. Similarly, when one sees that a white man gets gypsy neighbours and they start destroying everything and he can't stop it? The municipality doesn't help him, nor the state. So if you see something like that, it eats away and, in the end, it might lead to a conflict, a murder or massacre, as happened in the case of Harman, when he killed that whole gypsy family in 2010. No one really knows what happened before but he had had problems and no one helped him, so he solved it in the most radical way. (Bobo, Trnava)

Political populism and radicalism as represented by Kotleba and his party is not viewed generally as a good method for resolving this inequality: "I don't think Roma issues can be solved by populism. That would be the worst case" (Bohdan, Trnava). However, there are some who support extreme measures, for example: "I agree with the radical solution of Marian Kotleba, because there is nobody else who would help us" (Marianna, Trnava); or, "we have no other option than radical solutions" (ibid.). Such sentiments are fuelled by a sense that the Roma are

\footnotetext{
${ }^{44}$ Marcela Bieliková, Prejavy intolerancie, násilia a extrémizmu u mladých l'udí vo veku 13 až 18 rokov (Bratislava: Iuventa, 2009) // http://www.iuventa.sk/sk/Vyskum-mladeze/Novinky/Prejavy-intolerancienasilia-a-extremizmu-u-mladych-ludi-vo-veku-13-az-18-rokov.alej (accessed October 15, 2013).
} 
privileged somehow over the majority of society and benefit from "too much affirmative action for them" (Jakub, Rimavská Sobota). One respondent claims, "they get houses, destroy them, and then ask for new ones, they get them, move there and again destroy them" (Duro, Rimavská Sobota). Even though the Roma are considered a minority or marginalized community, according to the interviewees they enjoy much better opportunities than others who are working: "Roma have cheaper living costs, they get more state support for doing nothing, they only do bad things and ruin everything" (Kristinka, Rimavská Sobota).

Negative statements considerably outweigh positive sentiments towards Roma. Only several references were recorded in which Roma were viewed positively. These included references to having Roma neighbours or acquaintances: "We have gypsy neighbours who behave well" (Jenny, Trnava); "I know decent Roma" (Lucia, Trnava). They also blamed the media for negative stereotyping: "People have issues against Roma because of media power" (Vojtech, Rimavská Sobota). However, such statements constitute exceptions to the rule.

A number of statements refer to personal beliefs or experiences with Roma. These range from banal xenophobic statements such as "I don't like Roma" (Miriam, Rimavská Sobota) or "they can't speak Slovak" (Jakub, Rimavská Sobota) to claims that relations between Slovak and Roma communities constitute "a reciprocal racism" (Barbora, Rimavská Sobota). Respondents also felt their right to redress was limited, complaining that "there are no legal ways to penalise Roma" (Jenny, Trnava) and that declaring their own feelings honestly might lead to being labeled a racist, which would cause them problems either in school, social networks or in public affairs.

\section{CONCLUSION 45}

The continual strength and support for the Hungarian extremists might be explained similarly to the case in Slovakia. The traditional conservative political actors resist promptly reacting to the critical junctures that their societies are currently dealing with. Newly formed parties promise radical changes and prompt reactions in managing the society's needs and inequality. This can be considered a possible cure for the neglected problems that have been consistently falling behind state policy for the past twenty years. The failure of the states' strategies in integrating the Roma population in both countries gave the legitimacy to extremist formations that operate on the boundaries of their democratic and authoritarian

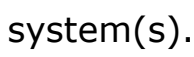

45 Some of the material in this section is also presented in the research report of the MYPLACE project: Jaroslav Mihálik and Peter Horváth, supra note 39. 
Another argument for the national to ethnic transition in Slovakia and Hungary may be the forgetting of historical grievances. The younger generation is not directly related to the history of Hungarian empire or kingdom. More likely, the young people are influenced by the legal and social system they were raised in and live in. In the differing attitudes about social welfare and diverse ethnic composition of the state, we can see the sources of the new waves of ethnic nationalism. In other words, social status and everyday life is something that ordinary people encounter much intensively than a language issue conflict between Bratislava and Hungary. However, the social welfare and state support, together with an inadequate political agenda for over twenty years, is something that is failing in the eyes of the voters. Thus, some of them feel the need to change the status quo, in respect to housing, employment, health care and education measures and affirmative action of the Roma population.

A nice example can be observed in Slovakia; the typical rhetoric of SNS aimed against the southern neighbor was slightly supplemented with ethno-nationalism during the elections in 2010 and 2012. Neither 2010 nor 2012 brought significant public trust or relevance for the SNS political party. This has resulted in changes at the post of the party leader. Ján Slota has become the honorary president of the party. The changes initiated so far in their party politics can be described as well as the reform. According to the SNS website, the party aims to interchange the insulting nationalism to patriotism, and the threat of confrontation should be transformed into dialogue with all political partners across the party system. They claim that they will negotiate with the representatives of Hungarian parties. ${ }^{46}$ For the establishment of a more profound and radical political movement, L'S-Naše Slovensko wags a warning finger about future tensions among the members of the society. The relatively successful rates of public support for the extremist movement establish a basic two-fold problem: from the perspective of Slovakia as a member of supranational organizations who are keen to maintain the antidiscriminatory measures in the member states, and, from the perspective of the ordinary citizens who essentially exchanged the factor of an external interstate enemy for an inner foe, which, in many cases, might be even more cruel than the "innocent drivel" from previous years.

Roma, also called Gypsies by the interview respondents, evoke both social tolerance and intolerance. Respondents complained about unfair privileges granted to Roma. including the provision of state support and housing, not paying taxes and not working, and some even supported extremist solutions to the perceived

${ }^{46}$ Slovak National Party, "Interview with SNS Party Leader Andrej Danko," Žilinský večerník (February 2013) // http://www.sns.sk/aktuality/a-danko-pre-zilinsky-vecernik-nie-nacionalizmus-ale-vlastenectvonie-konfrontacia-ale-dialog/ (accessed March 18, 2013). 
problems. However, there were also some positive statements that Roma were sometimes better than 'us' and that issues with Roma could be resolved. However, respondents were unable to express how these issues might be addressed, and, in general, support for radicalism and extremism among young people has risen over recent years. Although support for radical solutions tends to remain at the level of words, action may be constrained primarily because young people do not want to be labelled extremists or racists because of the stigma attached to these terms. A combination of the persistence of social inequalities, state incapacity to improve the economic situation of families, and a rise in civic disengagement has increased support for the radical populists, especially among those young people who seek political alternatives.

\section{BIBLIOGRAPHY}

1. "Anger Grows in Hungary over Anti-Roma Article." guardian.co.uk (January 2013) // http://www.guardian.co.uk/world/2013/jan/08/anger-hungary-antiroma-article (accessed March 18, 2013).

2. Bauböck, Rainer, ed. "Dual Citizenship for Transborder Minorities? How to Respond to the Hungarian - Slovak Tit-for-Tat." EUI Working Papers (Robert Schuman Centre for Advanced Studies) 2010/75 // http://cadmus.eui.eu/bitstream/handle/1814/14625/RSCAS_2010_75.corr.pd f?sequence $=3$.

3. Bieliková, Marcela. Prejavy intolerancie, násilia a extrémizmu u mladých l'udí vo veku 13 až 18 rokov. Bratislava: Iuventa, 2009 // http://www.iuventa.sk/sk/Vyskum-mladeze/Novinky/Prejavy-intolerancienasilia-a-extremizmu-u-mladych-ludi-vo-veku-13-az-18-rokov.alej (accessed October 15, 2013)

4. Brubaker, Rogers. Nationalism Reframed. Nationhood and the National Question in the New Europe. Cambridge: Cambridge University Press, 1996.

5. Dančák, Břetislav, and Petr Fiala. Národnostní politika v postkomunistických zemích. Brno: Masarykova univerzita, 2000.

6. Drál', Peter. "Lenivost' ako „esencia" rómskej etnickej identity: kritická analýza diskurzu slovenskej sociálnej politiky": 189-224. In: Findor Drál.' Ako skúmat' národ. Devät štúdií o etnicite a nacionalizme. Brno: Tribun, 2009.

7. Dunai, Marton. "Thousands rally in anti and pro Roma marches in Hungary." National Post (October 2012) // http://news.nationalpost.com/2012/10/17/thousands-rally-in-anti-and-proroma-marches-in-hungary/ (accessed March 19, 2013) 
8. European Union Agency for Fundamental Rights. The Situation of Roma in 11 EU Member States: Survey Results at a Glance. Luxembourg: Publications Office of the European Union, 2012.

9. Flašíková-Beňová, Monika, Hannes Swoboda, and Jan Marinus Wiersma. Roma: A European Minority. The Challenge of Diversity. European Union: Group of the Progressive Alliance of Socialists and Democrats in the European Parliament, 2011.

10. Gyarfášová, Ol'ga. "Slovenské parlamentné vol'by 2010: nacionálna agenda na ústupe?" Central European Political Studies Review Part 1, Vol. 13 (Winter 2011) // http://www.cepsr.com/clanek.php?ID=432.

11. Horváth, Peter, and Jaroslav Mihálik. "SMER-SD and FIDESZ: The National Interests and Populism in the 2010 Parliamentary Elections." Innovative Issues of Advanced Social Studies 2 (2011): 44-61.

12. Immigration and Refugee Board of Canada. "Roma in Hungary" (March 1998) // http://www.unhcr.org/refworld/docid/3ae6a823c.html (accessed March 16, 2013).

13. Kottasová, Ivana. "Jobbik's Anti-Roma Crusade." Presseurop (June 2009) // http://www.presseurop.eu/en/content/article/28071-jobbiks-anti-romacrusade (accessed March 8, 2013).

14. Kovats, Martin. "The politics of Roma identity: between nationalism and destitution." Open Democracy (July 2003) //

http://www.opendemocracy.net/people-migrationeurope/article_1399.jsp (accessed March 18, 2013).

15. Krivošíková, Blažena. "Slovenský 'nacionalizmus' a mad’arská hysteria." Prečo? Týždenník literatúry faktu //

http://www.chelemendik.sk/docpreco.php?d=00000198 (accessed January 5, 2013)

16. Labuda, Dušan. "Jazykové práva národnostných menšín v Československej republike": 119-131. In: Jana Šutajová and Mária Ďurkovská, eds. Madarská menšina na Slovensku $v$ procesoch transformácie po roku 1989 (Identita a politika II). Prešov: Universum, 2008.

17. Lászlóová, Klaudia. "Menšinové samosprávy v Mad’arsku." SME (October 1998) // http://www.sme.sk/c/2168718/mensinove-samospravy-vmadarsku.html (accessed March 12, 2013).

18. Lelkes, Gábor, and Károly Tóth. Národnostné a etnické menšiny na Slovensku 2006. Šamorín: Fórum inštitút pre výskum menšín, 2008.

19. Mareš, Miroslav. "The Extreme Right in Eastern Europe and Territorial Issues." Central European Political Studies Review Part 2-3, Vol. 11 (2009) // 
http://www.cepsr.com/clanek.php?ID=367.

20. McGarry, Aidan. Who Speaks for Roma? Political Representation of a Transnational Minority Community. New York: Continuum, 2010.

21. Mesežnikov, Grigorij. "Slovak Parliamentary Elections 2012: Is Radical Nationalism Rising or on the Decline?" deconspirator.com (June 2012) // http://deconspirator.com/2012/06/13/slovak-parliamentary-elections-2012is-radical-nationalism-rising-or-on-the-decline/ (accessed March 18, 2013).

22. Mihálik, Jaroslav, and Juraj Marušiak. "The dynamics of Slovak-Hungarian relations - the shift from language issues to legal and symbolic questions." Baltic Journal of Law and Politics Vol. 7, No. 1 (2014): 128-148 // DOI: $10.2478 /$ bjlp-2014-0008.

23. Mihálik, Jaroslav, and Peter Horváth. "Deliverable 5.3:Country based reports on interview findings" (November 2013) // http://www.fp7myplace.eu/documents/D5.3\%20Slovakia.pdf.

24. Mudde, Cas. "Racist Extremism in Central and Eastern Europe." East European Politics and Societies Vol. 19, No. 161 (2005): 161-184.

25. No author named. "ECRI Report on Hungary." European Commission Against Racism and Intolerance (February 2009) // http://www.coe.int/t/dghl/monitoring/ecri/country-by-country/hungary/HUNCbC-IV-2009-003-ENG.pdf (accessed March 14, 2013).

26. No author named. "Slovak nationalists incite anti-Roma hatred." hopenothate.org.uk (February 2012) //

http://www.hopenothate.org.uk/international/article/55/slovak-nationalistsincite-anti-roma-hatred (accessed March 18, 2013)

27. Nociar, Tomáš. "Right-wing extremism in Slovakia." International Policy Analysis (December 2012) // http://library.fes.de/pdf-files/id-moe/09567.pdf (accessed October 23, 2013).

28. Poláčková, Zuzana. "Nebezpečné stereotypy o postavení mad’arskej menšiny na Slovensku": 54-65. In: Jana Šutajová, ed. Mad'arská menšina na Slovensku $v$ procesoch transformácie po roku 1989 (Historické, politologické a právne súvislosti). Volume II. Prešov: Universum, 2008.

29. "Romani in Hungary." European Commission (October 2006) // http://ec.europa.eu/languages/euromosaic/hu3_en.htm (accessed March 11, 2013).

30. Schleinstein, Natalija, Dagmar Sucker, Agnieszka Wenninger, and Anja Wilde. Roma in Central and Eastern Europe. Thematic Series 2009/02: Social Sciences Eastern Europe. GESIS Leibniz Institute for the Social Sciences, 2009. 
31. SITA. "Mad’arská strana Jobbik je podla prieskumu druhá najpopulárnejšia." Pravda (March 2012) // http://spravy.pravda.sk/svet/clanok/242024madarska-strana-jobbik-je-podla-prieskumu-druha-najpopularnejsia/ (accessed March 18, 2013).

32. Slovak National Party Electoral Campaign // http://www.sns.sk/mediatlacovebesedy/p-sns-v-mediach/2012-predvolebna-kampan/ (accessed March 18, 2013).

33. Slovak National Party. "Interview with SNS Party Leader Andrej Danko." Žilinský večerník (February 2013) // http://www.sns.sk/aktuality/a-dankopre-zilinsky-vecernik-nie-nacionalizmus-ale-vlastenectvo-nie-konfrontacia-aledialog/ (accessed March 18, 2013).

34. Statistical Office of Slovakia. "Citizens' Census of 2011, 2001, 1991" // http://portal.statistics.sk/files/tab-10.pdf (accessed February 10, 2013).

35. Szaló, Csaba. "Národnostní politika v Mad’arsku: realita a vize samosprávy menšin": 172-187. In: Břetislav Dančák and Petr Fiala, eds. Národnostní politika v postkomunistických zemích. Brno: Masarykova univerzita, 2000.

36. Thorpe, Nick. "March by Far Right Raises Concern for Hungary's Roma." bbc.co.uk (October 2012) // http://www.bbc.co.uk/news/world-europe19992263 (accessed March 19, 2013).

37. World Directory of Minorities and Indigenous Peoples. "Hungary Overview" // http://www.minorityrights.org/?lid=5804\# (accessed March 11, 2013).

\section{LEGAL REFERENCES}

1. Act CXXV of 2003 on Equal Treatment and Promotion of Equal Opportunities // http://www.egyenlobanasmod.hu/data/SZMM094B.pdf (accessed February $27,2013)$.

2. Constitution of the Slovak Republic (September 1992) // http://www.nrsr.sk/web/Static/sk-SK/NRSR/Doc/zd_ustava_2012.pdf (accessed March 18, 2013).

3. The Law on Anti-discrimination in Slovakia. Collection of Laws, 2004, no. 365.

4. The Law on Labelling in Minority Languages in Slovakia. Collection of Laws, 1994, no. 191.

5. The Law on Registry Office in Slovakia. Collection of Laws, 1994, no. 154.

6. The Law on State Language in Slovakia. Collection of Laws, 1995, no. 270.

7. The Law on Use of Languages of National Minorities. Collection of Laws, 1999, no. 184. 